\title{
IN VITRO EVALUATION OF HYPOLIPIDEMIC EFFECT OF EXTRACTS OF MEDICINAL DRACAENA CINNABARI BALF. F. RESIN
}

\section{YASSER HUSSEIN EISSA MOHAMMED ${ }^{1,2}$, DEEPIKA HS ${ }^{1}$, FARES HEZAM AL-OSTOOT ${ }^{1,3}$, ZABIULLA $^{1}$, ANILAKUMAR $^{4}$ SHAUKATH ARA KHANUM ${ }^{*}$}

${ }^{1}$ Department of Chemistry, Yuvaraja's College, University of Mysore, Mysuru, Karnataka, India. ${ }^{2}$ Department of Biochemistry, Faculty of

Applied Science College, University of Hajjah, Hajjah, Yemen. ${ }^{3}$ Department of Biochemistry, Faculty of Education and Science, Al-Baydha University, Albaydha, Yemen. ${ }^{4}$ Applied Nutrition Division, Defence Food Research Laboratory, Mysuru, India. Email: shaukathara@yahoo.co.in

Received: 09 March 2019, Revised and Accepted: 03 August 2019

\begin{abstract}
Objective: The objective of the study was to in vitro evaluate of hypolipidemic effect of extracts of medicinal Dracaena cinnabari Balf. f. resin.

Methods: About $800 \mathrm{~g}$ of dry powder of the resin of dracaena cinnabar was taken in a Soxhlet apparatus and subjected for sequential extraction of solvents from non-polar to polar end (hexane, benzene, diethyl ether, dichloromethane, chloroform, ethyl acetate, acetone, ethanol, methanol, and water); the extract samples were kept at $4^{\circ} \mathrm{C}$ for further assays. All the extracts were subjected to glucose uptake assay.

Results: The ethanol extract showed significant $(\mathrm{p}<0.05)$ hypolipidemic effect by decreasing the activity of enzyme such as significant reduction in the pancreatic lipase enzyme, malic dehydrogenase enzyme, and glucose-6-phosphate dehydrogenase enzyme with IC ${ }_{50} \sim 13, \sim 13$, and $\sim 14$, respectively. This results were similar to the standard drug atorvastatin with $\mathrm{IC}_{50} \sim 12, \sim 16$, and $\sim 17$, respectively. Ethanol extract exhibited significant atherogenic index and percentage protection against hyperlipidemia. The potential biological activity of ethanol extract may be attributed to the highest polarity which needs further investigation.
\end{abstract}

Conclusion:

Keywords: Dracaena cinnabari, Enzyme inhibition, Glucose-6-phosphate dehydrogenase, Malate dehydrogenase, Soxhlet.

(C) 2019 The Authors. Published by Innovare Academic Sciences Pvt Ltd. This is an open access article under the CC BY license (http://creativecommons. org/licenses/by/4. 0/) DOI: http://dx.doi.org/10.22159/ajpcr.2019.v12i10.32984

\section{INTRODUCTION}

One of the most common vital threats for the accelerated atherosclerosis and cardiovascular diseases is hyperlipidemia [1,2]. It is considered as one of the diseases which have it is own problematic consequences and impact on the health of a human. This disease has a direct relation with the food system that a person adopts in his daily life. To avoid being threatened by this disease, a person can do some exercises and eating healthy food. The formation of plaques in the walls of coronary arteries is one of the characteristics of atherosclerosis by reducing the flow of blood, leading to coronary artery disease. Hypercholesterolemia contributes to the increased prevalence of coronary artery diseases [3]. To reduce the risk of coronary artery diseases, so many studies were conducted and most of them stated that lowering of serum cholesterol is one of those beneficial ways for the reduction of risk [4]. Ayurveda which is an Indian traditional medicine includes a large number of plants which are categorized as hypolipidemic. Three main pathways are responsible for the synthesis and transport of lipids within the body: Exogenous, endogenous, and reverse cholesterol transport. The pictorial representation is given in Fig. 1 [5]. Dragon's blood tree is a non-specific name for dark red resinous exudations from different plant species endemic to various regions around the globe that belongs to four genera Dracaena spp. [6]. A wide-ranging research over the decades on this plant indicated that it is a persuasive therapeutic agent against various diseases. Dragon's blood has been found to be safe even at very high doses in human clinical trials [7]. It has so many treatment uses, but due to the bioavailability of this tree, it has no effective therapeutic molecule [8].

\section{MATERIALS AND METHODS}

Materials

The commercially available refined avocado oil was used for extraction from Sigma Chemical Company, USA. Other chemicals used in the studies were of analytical grade and purchased from SDFCL, Mumbai, India.
The enzyme, NADP-malic enzyme (EC 1.1.1.40) was obtained from Sigma-Aldrich, Bengaluru. The other enzymes glucose-6-phosphate dehydrogenase (EC 1.1.1.49) and pancreatic lipase (EC 3.1.1.3) were purchased from SRL, India.

\section{Methods}

Collection of plant material

The resin of dragon's blood tree (Dracaena cinnabari) was brought from the origin of this tree from Socotra Island, Republic of Yemen. It has a matchless and strange appearance, described as upturned, densely packed crown having the shape of an umbrella [4].

\section{Preparation of extracts}

About $800 \mathrm{~g}$ of dry powder of the resin of dracaena cinnabar was taken in a Soxhlet apparatus and subjected for sequential extraction of solvents from non-polar to polar end (hexane, benzene, diethyl ether, dichloromethane, chloroform, ethyl acetate, acetone, ethanol, methanol, and water); the extract samples were kept at $4{ }^{\circ} \mathrm{C}$ for further assays. All the extracts were subjected to glucose uptake assay [7].

\section{Inhibition of pancreatic lipase activity}

The hypolipidemic ability of plant extracts was tested by assessing the pancreatic lipase inhibition assay [9]. Plant extracts were individually incubated with $1 \mathrm{ml}$ of reaction mixture containing 1 unit of lipase enzyme and $100 \mathrm{mM}$ phosphate buffer (pH 7.2) with Triton-X-100 (0.5\%). The enzyme reaction was started by adding p-nitrophenyl butyrate $(5 \mathrm{mM}$ in acetonitrile) and monitored at $340 \mathrm{~nm}$. A control tube was maintained and the result was expressed as percent activity.

Inhibition of glucose-6-phosphate dehydrogenase activity

Glucose-6-phosphate dehydrogenase activity was measured by monitoring reduction of NADP at $340 \mathrm{~nm}$ [10]. Plant extracts were 


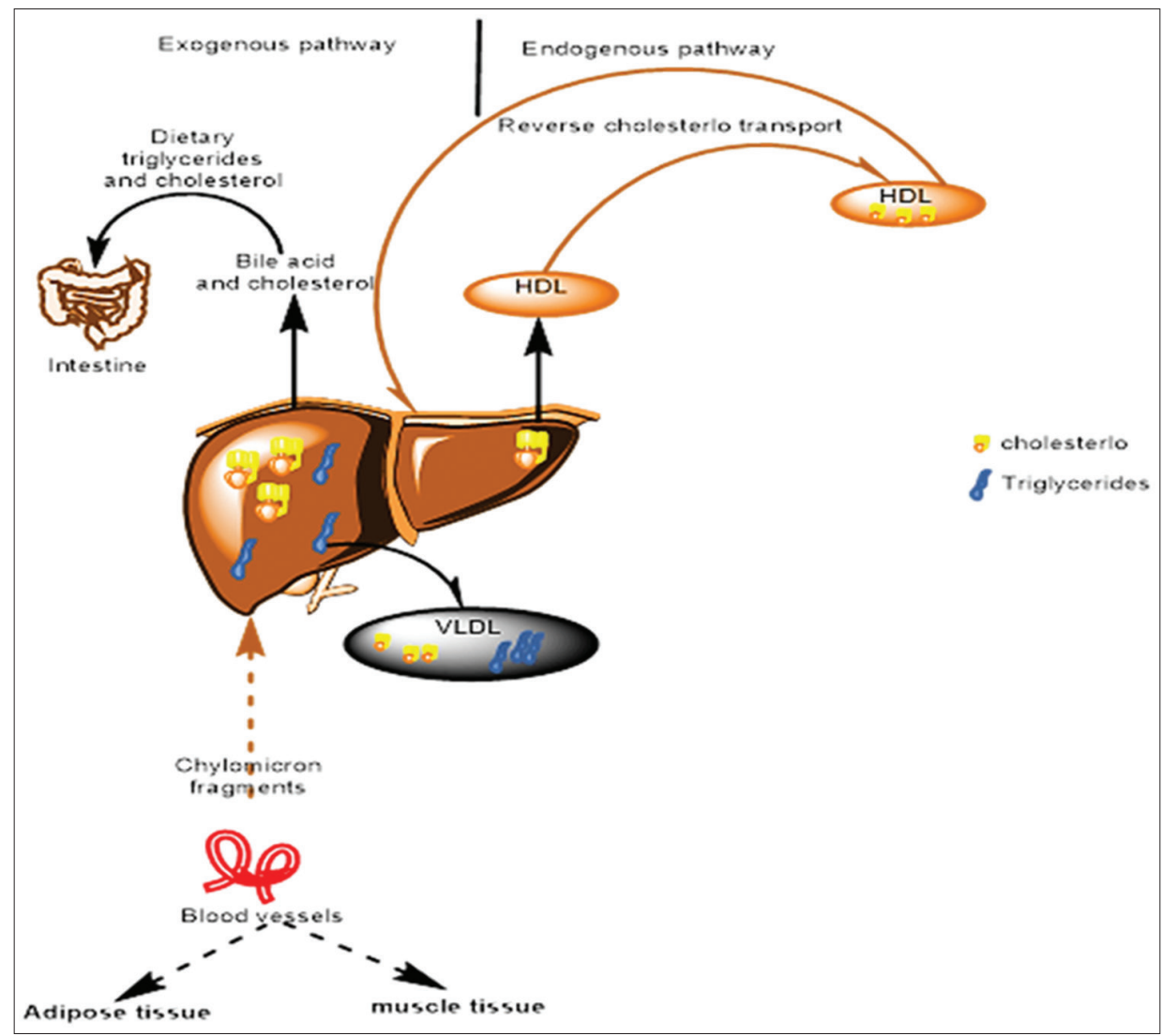

Fig. 1: Pathways of lipid metabolism

Table 1: Inhibitory concentration of plant extracts at 25-75 $\mu \mathrm{M}$ concentrations

\begin{tabular}{|c|c|c|c|c|}
\hline $\begin{array}{l}\text { Sample description } \\
\text { parts solvent }\end{array}$ & Concentrations 25-75 $\mu \mathrm{M}$ & Pancreatic lipase $(\mu \mathrm{M})$ & Malic dehydrogenase $(\mu M)$ & $\begin{array}{l}\text { Glucose-6-phosphate } \\
\text { dehydrogenase }(\mu \mathrm{M})\end{array}$ \\
\hline \multirow[t]{3}{*}{ Hexane } & 25 & 35.30 .01 & $30.3 \pm 0.07$ & $40.1 \pm 0.14$ \\
\hline & 50 & $30.2 \pm 0.07$ & $29.6 \pm 0.05$ & $31.3 \pm 0.01$ \\
\hline & 75 & $25.0 \pm 0.17$ & $22.1 \pm 0.07$ & $26.6 \pm 0.07$ \\
\hline \multirow[t]{3}{*}{ Benzene } & 25 & $55.2 \pm 1.12$ & $50.4 \pm 0.12$ & $66.1 \pm 0.14$ \\
\hline & 50 & $45.2 \pm 0.02$ & $50.9 \pm 6.02$ & $72.4 \pm 2.09$ \\
\hline & 75 & $50.2 \pm 2.00$ & $44.2 \pm 1.00$ & $62.1 \pm 0.03$ \\
\hline \multirow{2}{*}{ Diethyl ether } & 50 & $33.9 \pm 0.05$ & $63.0 \pm 1.4$ & $42.5 \pm 0.09$ \\
\hline & 75 & $31.9 \pm 3.07$ & $55.0 \pm 0.21$ & $45.1 \pm 1.50$ \\
\hline \multirow[t]{3}{*}{ Chloroform } & 25 & $48.9 \pm 9.00$ & $69.0 \pm 0.20$ & $55.9 \pm 0.10$ \\
\hline & 50 & $45.2 \pm 0.01$ & $52.2 \pm 0.21$ & $53.1 \pm 3.00$ \\
\hline & 75 & $39.9 \pm 0.11$ & $49.9 \pm 0.40$ & $50.0 \pm 0.8$ \\
\hline \multirow[t]{3}{*}{ Ethyl acetate } & 25 & $38.2 \pm 0.20$ & $44.4 \pm 0.01$ & $49.0 \pm 1.07$ \\
\hline & 50 & $36.9 \pm 2.00$ & $41.6 \pm 9.01$ & $44.9 \pm 1.20$ \\
\hline & 75 & $29.2 \pm 0.09$ & $39.1 \pm 2.00$ & $41.5 \pm 0.06$ \\
\hline \multirow{2}{*}{ Dichloromethane } & 50 & $33.0 \pm 0.01$ & $41.0 \pm 0.03$ & $39.9 \pm 0.08$ \\
\hline & 75 & $30.6 \pm 6.00$ & $42.9 \pm 9.00$ & $36.0 \pm 1.02$ \\
\hline \multirow[t]{3}{*}{ Acetone } & 25 & $35.3 \pm 0.01$ & $36.6 \pm 0.25$ & $31.0 \pm 0.21$ \\
\hline & 50 & $28.9 \pm 9.11$ & $34.2 \pm 2.05$ & $30.9 \pm 5.00$ \\
\hline & 75 & $25.0 \pm 2.00$ & $31.8 \pm 0.20$ & $30.0 \pm 0.01$ \\
\hline \multirow[t]{3}{*}{ Ethanol } & 25 & $14.2 \pm 1.10$ & $17.1 \pm 0.05^{*}$ & $17.4 \pm 0.04^{*}$ \\
\hline & 50 & $13.0 \pm 1.05^{*}$ & $12.1 \pm 1.00$ & $14.0 \pm 0.02 *$ \\
\hline & 75 & $12.9 \pm 0.02 *$ & $11.1 \pm 0.05^{*}$ & $13.9 \pm 0.04 *$ \\
\hline \multirow[t]{3}{*}{ Methanol } & 25 & $29.4 \pm 0.02$ & $29.9 \pm 0.08$ & $30.1 \pm 0.032$ \\
\hline & 50 & $24.0 \pm 9.00$ & $24.3 \pm 0.02$ & $27.4 \pm 0.09$ \\
\hline & 75 & $23.0 \pm 0.09$ & $24.4 \pm 0.11$ & $24.9 \pm 0.12$ \\
\hline \multirow[t]{3}{*}{ Water } & 25 & $35.1 \pm 0.07$ & $31.9 \pm 0.09$ & $30.2 \pm 1.00$ \\
\hline & 50 & $31.8 \pm 1.02$ & $29.2 \pm 0.82$ & $23.3 \pm 0.07$ \\
\hline & 75 & $31.0 \pm 9.00$ & $27.0 \pm 0.08$ & $20.1 \pm 4.07$ \\
\hline \multirow[t]{3}{*}{ Standard atorvastatin } & 25 & $13.1 \pm 0.10$ & $17.1 \pm 0.09$ & $20.1 \pm 0.20$ \\
\hline & 50 & $13.0 \pm 1.10$ & $19.1 \pm 0.01^{* *}$ & $17.0 \pm 0.22$ \\
\hline & 75 & $12.1 \pm 9.09$ & $14.1 \pm 1.00$ & $16.4 \pm 1.00$ \\
\hline
\end{tabular}

Statistically significant values are expressed as ${ }^{*} \mathrm{p}<0.05$ and ${ }^{* *} \mathrm{p}<0.01$ 
individually incubated with $1 \mathrm{ml}$ of reaction mixture containing 0.5 units of enzyme, $50 \mathrm{mM}$ tris $\mathrm{HCl}(\mathrm{pH} \mathrm{7.4})$, and $0.1 \mathrm{mM}$ glucose-6phosphate. The enzyme reaction was started by adding 0.15 mM NADP and monitored at $340 \mathrm{~nm}$. A control tube was maintained and the result was expressed as percent activity.

\section{Inhibition of malic dehydrogenase activity}

Malic dehydrogenase activity was measured by monitoring reduction of NADP at $340 \mathrm{~nm}[11,12]$. Plant extracts were incubated with $1 \mathrm{ml}$ of tris $-\mathrm{HCl}(100 \mathrm{mM}, \mathrm{pH} 7.4)$ containing 0.5 unit of malic dehydrogenase enzyme, L-malate (10 mM), and $\mathrm{MnCl} 2$ (2 mM). The enzyme reaction was started by adding $2 \mathrm{mM}$ NADP and monitored at $340 \mathrm{~nm}$. A control tube was maintained and the result was expressed as percent activity.

\section{Statistical analysis}

Values were expressed as mean \pm standard deviation. MS Excel 8.1 version software was used for data analysis; statistical significance was evaluated by one-way analysis of variance followed by two-tailed Student's t-test. Statistically significant values were expressed as ${ }^{*} \mathrm{p}<0.05$ and ${ }^{* *} \mathrm{p}<0.01$.

\section{RESULTS AND DISCUSSION}

Hypolipidemic decrease by the effect of the pancreatic lipase, malic dehydrogenase, and glucose-6-phosphate dehydrogenase enzymes

The enzyme inhibition studies of the glucose-6-phosphate dehydrogenase were evaluated at different concentrations (25, 50 , and $75 \mu \mathrm{M}$ ) of the resin of dragon's blood. It was noticed that while performing the test for the enzyme inhibition of the glucose6-phosphate dehydrogenase, the other extracts showed moderate and unsignificant effects compared to the ethanol extract which showed significant hypolipidemic effect by decreasing the activity of enzyme with $\mathrm{IC}_{50} \sim 13$. Furthermore, the significant effect of ethanol extract was obviously noticed by reduction in the pancreatic lipase enzyme with $\mathrm{IC}_{50} \sim 13$ and these results gave us motivation to pursue our work. Compared to the previous investigations, the malic dehydrogenase enzyme was also reduced by the effect of ethanol extract with $\mathrm{IC}_{50} \sim 14$. It was proved that the results of this investigation were similar to the standard drug atorvastatin with IC $_{50} \sim 12, \sim 16$, and $\sim 17$, respectively. Ethanol extract exhibited significant atherogenic index and percentage protection against hyperlipidemia (Table 1). The potential biological activity of ethanol extract may be attributed to the highest polarity which needs further investigation.

\section{CONCLUSION}

This study of the extraction of D. cinnabari Balf. f. was conducted to estimate hypoglycemic effects of the extracts by the inhibition assays of the enzymes pancreatic lipase, glucose-6-phosphate dehydrogenase, and malate dehydrogenase. All the assessments performed for the extracts exhibited hypolipidemic activity by attenuating the activity of the enzymes studied. Ethanol extract was found to be a more potent enzyme inhibitor. From our present investigations, ethanol extract could be concluded as promising hypolipidemic agent.

\section{ACKNOWLEDGMENTS}

Yasser Hussein Eissa Mohammed is thankful to the University of Hajja, Yemen, for providing financial assistance under the teacher's fellowship. Fares Hezam Al-Ostoot is thankful to Al-Baydha University, Yemen, for providing financial assistance under the teacher's fellowship. Zabiulla gratefully acknowledges the financial support provided by the Department of Science and Technology, New Delhi, under INSPIREFellowship scheme (IF140407). Shaukath Ara Khanum expresses sincere gratitude to the Government of Karnataka, Vision Group on Science and Technology, Bangalore, for the financial assistance and support (VGST/CISEE/2012-13/282 dated March 16, 2013) and UGC, New Delhi, under the Major Research Project Scheme (F.39/737/2010 [SR]). Authors are also thankful to Director, Defence Food Research Laboratory, Mysuru, India, for support to carry out the analytical work.

\section{AUTHORS' CONTRIBUTIONS}

The author declares that this work was done by the authors named in this article.

\section{CONFLICTS OF INTEREST}

No conflicts of interest are associated with this work

\section{REFERENCES}

1. Chouhan H, Purohit A. The protective effect of cumin (Cuminum cyminum L.) seed extract on cardiovascular system toxicity and hematology on hyperlipidemic rabbits: An experimental study. Asian J Pharm Clin Res 2018;11:353-6.

2. Subashini S, Kripa Kg, Pugalendi Kv. Hypolipidemic potential of methanolic extract of Gracilaria corticata on streptozotocin-induced diabetic rats. Asian J Pharm Clin Res 2017;10:402-5.

3. Libby P, Ridker PM, Maseri A. Inflammation and atherosclerosis. Circulation 2002; 105:1135-43.

4. Randomised trial of cholesterol lowering in 4444 patients with coronary heart disease: The scandinavian simvastatin survival study (4S). Lancet 1994;344:1383-9.

5. Patwardhan B, Vaidya AD, Chorghade M. Ayurveda and natural products drug discovery. Curr Sci 2004;86:789-99.

6. Mohammed YH, Khanum SA. Anti-diabetic activity of Dracaen cinnabari Balf.f extracts from resin in Socotra Island-Yemen. J Plant Biochem Physiol 2016;4:162.

7. Mohammed YH. In vitro anti-cancer activity of extracts Dracaen cinnabari Balf.f resin from Socotra Island in Yemen republic. Biochem Anal Biochem 2016;5:296.

8. Su J, Wang H, Ma C, Liu C, Rahman MT, Gao C, et al. Hypolipidemic mechanism of gypenosides via inhibition of pancreatic lipase and reduction in cholesterol micellar solubility. Eur Food Res Technol 2016;242:305-12.

9. Puneeth HR, Ananda H, Kumar KS, Rangappa KS, Sharada AC. Synthesis and antiproliferative studies of curcumin pyrazole derivatives. Med Chem Res 2016;25:1842-51.

10. Xu Y, Osborne BW, Stanton RC. Diabetes causes inhibition of Glucose6-phosphate dehydrogenase via activation of PKA, which contributes to oxidative stress in rat kidney cortex. Am J Physiol Renal Physiol 2005;289:F1040-7.

11. Roobol A, Alleyne GA. A study of stabilization of gluconeogenic activity in rat liver slices by calcium and manganese ions. Biochem J 1972;129:231-9.

12. Kong C, Nimmo L, Elatrozy T, Anyaoku V, Hughes C, Robinson S, et al. Smoking is associated with increased hepatic lipase activity insulin resistance dyslipidaemia and early atherosclerosis in Type 2 diabetes. Atherosclerosis 2001;156:373-8. 